\title{
Effect of Cellulose-Ibeta Presence in Sawdust on Compressive Strength of Cement Paste
}

\author{
Abdoullah Namdar ${ }^{1} \&$ Fadzil Mat Yahaya $^{1}$ \\ ${ }^{1}$ Department of Civil Engineering \& Earth Resources, Universiti Malaysia Pahang, Malaysia \\ Correspondence: Abdoullah Namdar, Department of Civil Engineering \& Earth Resources, Universiti Malaysia \\ Pahang, Malaysia. E-mail: ab_namdar@yahoo.com
}

Received: December 3, 2013

Accepted: December 29, 2013 Online Published: March 11, 2014

doi:10.5539/mas.v8n2p107

URL: http://dx.doi.org/10.5539/mas.v8n2p107

\begin{abstract}
In this paper, enhancement of compressive strength of OPC paste is main objective. $1 \%$ and $4 \%$ of sawdust powder has been blended to Ordinary Portland Cement (OPC) paste. The compressive strength has been measured on 7, 28, 56 and 90 days. The micro properties of OPC paste has been investigated by using X-ray diffraction (XRD) and Atomic Force Microscopy_(AFM). The best quantity for replacement of sawdust is $1 \%$. The mixture of $4 \%$ sawdust to OPC paste has also been improved compressive strength of concrete. The cellulose-Ibeta presences in saw dust, has been modified the surface roughness and hydration of OPC paste, and leads to enhancement of compressive strength of concrete. The compressive strength of OPC paste has been stabilized with increase of age, due to pozzolanic actions. The compressive strength of OPC has been decreased with increase sawdust contents.
\end{abstract}

Keywords: sawdust, XRD, AFM, micro properties, surface roughness

\section{Introduction}

Using recycle material in construction industry is a method for sustainable development. The agricultural solid waste is usable in construction industry in order to have an economical green building design. Among the various agriculture waste materials the sawdust produces in form of grounded particles size, and appears with good morphology and mineralogy for Ordinary Portland Cement (OPC) mixture.

A large quantity of greenhouse gases can be emitted during the storage of sawdust and wood chippings (Wihersaari, 2005). To develop a new composites building material for none or semi-structural panelling the waste wood, waste paper and Tradical lime have been used. The contribution of self-strength of Wood-Crete was due to the influence of the size of sawdust particles (Aigbomian \& Fan, 2013). The size of sawdust particles depends on the kind of wood and size of the saw's teeth (Afuwape, 1983). It is indicated (Coatanlem et al., 2006) that the wood chippings as fibers in concrete due to low cost proximity of the sources, and the potential pollution of wood wastes is interesting issue in developing new concrete and several other potential applications. There are research works in self-compactability concrete containing sawdust Ash (SDA) as powder material and naphthalene sulphonate (NS) and melamine sulphonate (MS). The results reported that the SDA can be used as powder material with cement and super-plasticizers to produce flowable concrete. The compressive strength development of SCC mortar shows a tremendous improvement over the control. At 90 days, the best strength was recorded at $10 \mathrm{wt} \%$ replacement and this is approximately $30 \%$ above the value of the control (Elinwa et al., 2008; EFNARC, 2002; Elinwa \& Mahmood, 2001). There is a research work on composite of water treatment sludge and sawdust to produce coarse lightweight aggregate for concrete. The produced concrete is suitable for application in non-structural elements (Sales et al., 2011). The limestone dust and wood sawdust have been used for producing a low-cost and lightweight brick. The produced brick has high acceptable deformation, low unit weight and smother surface compared to the current concrete bricks in the market (Turgut \& Algin, 2007). It has been reported that the wood ash has good potential for use as an activator in cement-based materials (Naik, 1999). An extensive review on utilization of wood ash in concrete manufacturing has been made, and indicates effect of wood ash on slump, water absorption and strength properties of concrete (Siddique, 2012). In this paper, the sieved grounded particles size of $<45 \mu \mathrm{m}$ as a natural admixture with ordinary Portland cement (OPC) paste has been investigated. The micro and macro properties of modified OPC pastes-sawdust mixture have been analyzed. It is aimed to introduce a natural additive for enhancing OPC paste compressive strength. The effect of 
Cellulose-Ibeta on surface roughness of OPC paste-sawdust mixture has been investigated.

\section{Methodology and Experiments}

\subsection{Materials and Cement Paste Mix Design}

Produce additive for OPC paste from agricultural solid waste is a significant important idea in concrete industry. The sawdust considers as an additive, it made in wood industry of Pahang province of Malaysia. The sawdust contents natural minerals. The additive has been used as admixtures along with OPC paste $(43 \mathrm{G})$ as a binding material. The produced cement paste tested in 7, 28, 56 and 90 days. The sawdust reform mineralogical characteristics of OPC paste. The work is made up base on trial mixes. To find appropriate proportion of additive, the materials mix ration has been done based on weight.

Table 1. Mix designs of the solidified wastes

\begin{tabular}{cc}
\hline Identity & W/C ratio \\
\hline OPC $(100 \%)$ & 0.37 \\
OPC $(99 \%)+$ sawdust $(1 \%)$ & 0.37 \\
OPC $(96 \%)+$ sawdust $(4 \%)$ & 0.37 \\
\hline
\end{tabular}

\subsection{Compressive Strength}

To obtain the effect of sawdust mixture of $(1 \%$ and $4 \%)$ on the compressive strength of OPC paste, cubical molds $(5 \mathrm{~cm} \times 5 \mathrm{~cm} \times 5 \mathrm{~cm})$ were prepared according water to cement ratio indicated in Table 1 . After initial curing of 1 day, the specimens were kept at water $25 \pm 5{ }^{\circ} \mathrm{C}$ for $7,28,56$ and 90 days. The compressive strength has been done as per ACI and the average value of three specimens has been selected for interpretation.

\section{$2.3 X R D$ and $A F M$}

X-ray diffractometry (XRD) and Atomic Force Microscopy (AFM) have been used to investigate on hydration process of OPC paste-Sawdust mixture on 28 days of curing. The samples were sieved and separated to a particle size of $<45 \mu \mathrm{m}$ for application of XRD analysis and AFM image and, in order to investigate on hydration and morphological characteristic of cement pastes.

\section{Results and Discussions}

There are the various waste agriculture materials. The sawdust, this waste agriculture is used for improve compressive strength of cement paste. The sawdust powder in quantity of $1 \%$ and $4 \%$ is blending in OPC paste. The compressive strength OPC in 7, 14, 28, 56 and 90 is measured. The best result is for replacement of $1 \%$ sawdust.The sawdust appears well admixtures to OPC paste. $1 \%$ of sawdust is very good modifying surface roughness of OPC paste. The proportion of $1 \%$ of sawdust in replacement of cement paste is recommended, it is resulted in good enhancement of compressive strength of OPC paste. The XRD results indicated Cellulose-Ibeta is presented in sawdust. The cellulose-Ibeta is controlling hydration of cement paste. The cellulose-Ibeta has also been improved compressive strength of cement paste. The surface roughness studied by AFM results. The surface roughness of cement paste has been modified by cellulose-Ibeta. The surface roughness of all cement paste specimens almost will be same after 90 days subsequently the close compressive strength has been appeared. This research work can help in commercialization of industrial solid waste. The results are indicated in this paper help for sustainable development and environment pollution solution. The research program is continued on how to improve the flexural strength and flexibility of thin cross section plain concrete. The formation of various crystalline phases and their effects on hydration behaviour of mineral admixtures blended cement were examined by X-ray diffraction (XRD). The changes in microstructure of the hydrated samples were also studied using (AFM). According to results in Table 2 when the age of specimen is reaching to near 90 days the compressive strength is more stabilizing. It is good agreement with previous research work is reported (Elinwa \& Mahmood, 2001). The results had shown the appropriate proportion of sawdust improves compressive strength of cement paste. The compressive strength development of cement paste shows a tremendous improvement over the control. At 56 days, the strength was recorded at $4 \mathrm{wt} \%$ replacement and this is approximately $20 \%$ above the value of the control. The recycle material is appropriate selection for developing composite sustainable reliable construction material. 
Table 2. Additive mixture ratio and compressive strength

\begin{tabular}{cccccc}
\hline $\begin{array}{c}\text { Sl. } \\
\text { No }\end{array}$ & $\begin{array}{c}\text { \% of } \\
\text { sawdust }\end{array}$ & $\begin{array}{c}\text { Compressive } \\
\text { strength after 7 days } \\
(\mathrm{MPa})\end{array}$ & $\begin{array}{c}\text { Compressive } \\
\text { strength after 28 days } \\
(\mathrm{MPa})\end{array}$ & $\begin{array}{c}\text { Compressive } \\
\text { strength after 56 days } \\
(\mathrm{MPa})\end{array}$ & $\begin{array}{c}\text { Compressive } \\
\text { strength after 90 days } \\
(\mathrm{MPa})\end{array}$ \\
\hline 1 & - & 25.37 & 30.10 & 34.13 & 35.12 \\
2 & 1 & 33.26 & 46.79 & 46.60 & 47.10 \\
3 & 4 & 28.75 & 33.61 & 40.99 & 41.32 \\
\hline
\end{tabular}

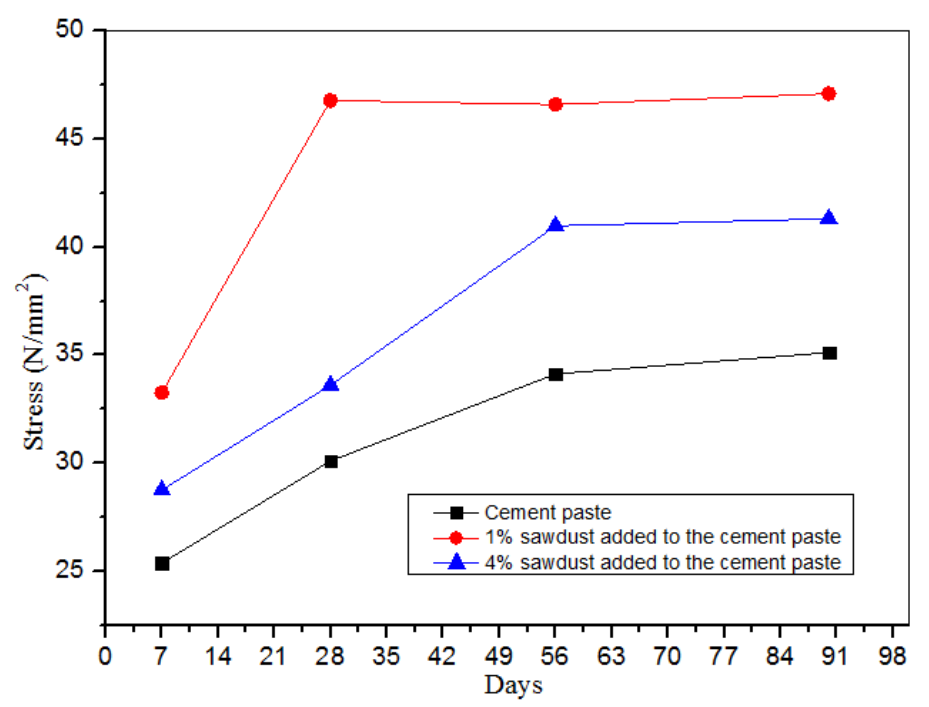

Figure 1. Compressive strength of OPC paste, modified by cellulose-Ibeta

It has been reported that the quantity of 5, 8 and $12 \%$ of wood ash content in the total cementitious materials improve compressive strength (Figure 2). The replacement of wood ash reduces cement consumption. This indicates contribution of wood fly ash to pozzolanic activity (Naik et al., 2002). The comparative of Figures 1 and 2 indicate that $1 \%$ of sawdust result in better compressive strength. And pozzolanic activity made stabilized compressive strength of OPC on 90 days.

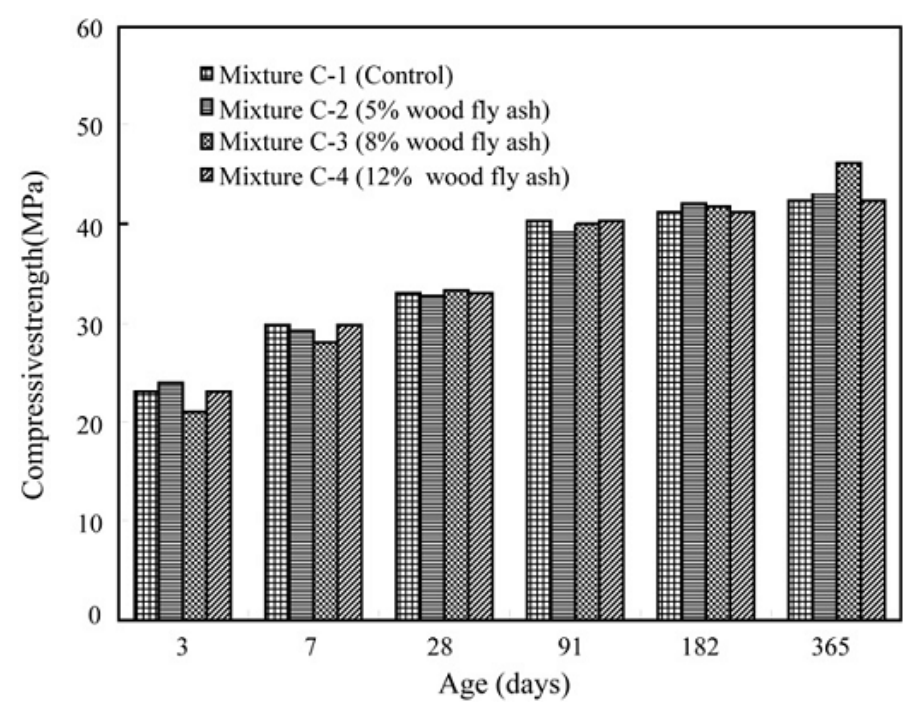

Figure 2. Compressive strength of concrete mixtures containing wood fly ash (Naik et al., 2002) 
Table 3. AFM roughness results for sawdust-cement paste

\begin{tabular}{|c|c|c|c|c|c|c|c|c|c|c|c|}
\hline \multirow[b]{2}{*}{$\begin{array}{c}\text { Material } \\
\text { composition }\end{array}$} & \multirow[b]{2}{*}{$\begin{array}{c}\text { Sample } \\
\text { name }\end{array}$} & \multicolumn{5}{|c|}{ Height parameters } & \multicolumn{2}{|c|}{ Shape parameters } & \multicolumn{3}{|c|}{ Other parameters } \\
\hline & & $\begin{array}{c}\mathrm{Sq} \\
\text { Root mean } \\
\text { square } \\
\text { roughness }\end{array}$ & $\begin{array}{c}\mathrm{Sa} \\
\text { Average } \\
\text { roughness }\end{array}$ & $\begin{array}{c}\text { St } \\
\text { Area } \\
\text { peak-to-valley } \\
\text { height }\end{array}$ & $\begin{array}{c}\mathrm{Sp} \\
\text { Maximum } \\
\text { area peak } \\
\text { height }\end{array}$ & $\begin{array}{c}\text { Sv } \\
\text { Maximum } \\
\text { area valley } \\
\text { depth }\end{array}$ & $\begin{array}{c}\text { Sku } \\
\text { Kurtosis }\end{array}$ & $\begin{array}{c}\text { Ssk } \\
\text { Skewness }\end{array}$ & $\begin{array}{c}\text { Sds } \\
\text { Area peak } \\
\text { density }\end{array}$ & $\begin{array}{c}\text { Sdq } \\
\text { Area root } \\
\text { mean } \\
\text { square } \\
\text { slope } \\
\end{array}$ & $\begin{array}{c}\text { Sda } \\
\text { Area } \\
\text { average } \\
\text { absolute } \\
\text { slope } \\
\end{array}$ \\
\hline Cement & Cement & $73.479 \mathrm{~nm}$ & $56.989 \mathrm{~nm}$ & $599.843 \mathrm{~nm}$ & $231.165 \mathrm{~nm}$ & $368.677 \mathrm{~nm}$ & 3.541 & -0.397 & $\begin{array}{c}26.556 \\
\text { 1/um*um }\end{array}$ & 0.607 & 0.617 \\
\hline Sawdust & Sawdust & $26.891 \mathrm{~nm}$ & $20.443 \mathrm{~nm}$ & $264.166 \mathrm{~nm}$ & $92.028 \mathrm{~nm}$ & $172.137 \mathrm{~nm}$ & 4.636 & -0.233 & $\begin{array}{c}37.595 \\
\text { 1/um*um }\end{array}$ & 0.279 & 0.200 \\
\hline $\begin{array}{c}\text { C } 99.0 \% \\
+\mathrm{S} 1 \%\end{array}$ & 1 & $143.427 \mathrm{~nm}$ & $112.307 \mathrm{~nm}$ & $1061.334 \mathrm{~nm}$ & $452.481 \mathrm{Nm}$ & $608.852 \mathrm{~nm}$ & 3.750 & -0.377 & $\begin{array}{c}13.640 \\
\text { 1/um*um }\end{array}$ & 1.027 & 0.968 \\
\hline $\begin{array}{c}\mathrm{C} 96.0 \% \\
+\mathrm{S} 4 \% \\
\end{array}$ & 4 & $59.194 \mathrm{~nm}$ & $42.483 \mathrm{~nm}$ & $620.928 \mathrm{~nm}$ & $264.433 \mathrm{~nm}$ & $356.494 \mathrm{~nm}$ & 6.586 & -0.547 & $\begin{array}{c}76.350 \\
1 / \text { um*um }\end{array}$ & 0.648 & 0.535 \\
\hline
\end{tabular}

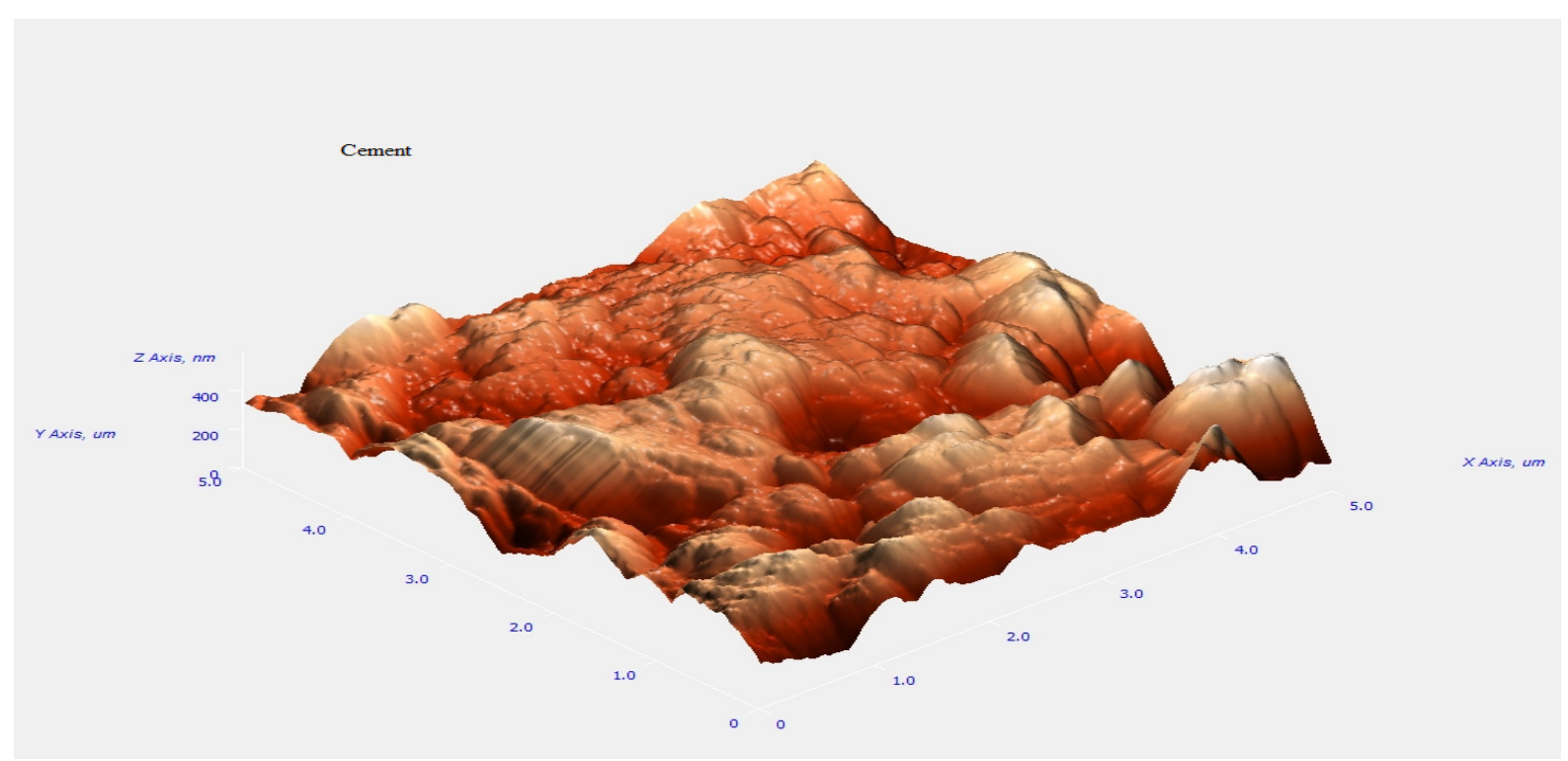

Figure 3. AFM image for OPC paste after 28 days

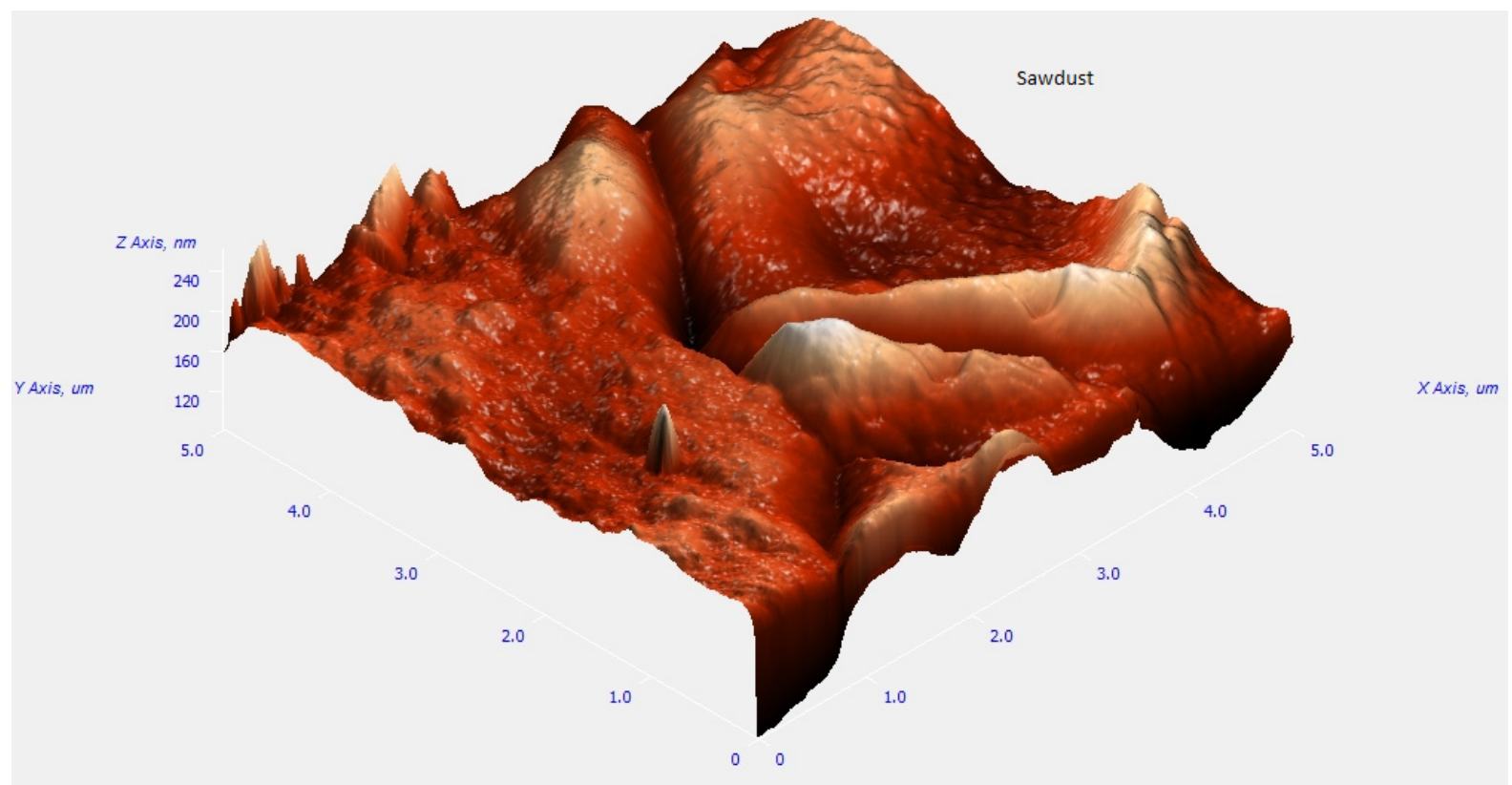

Figure 4. AFM image for sawdust grounded particles size of $<45 \mu \mathrm{m}$ 


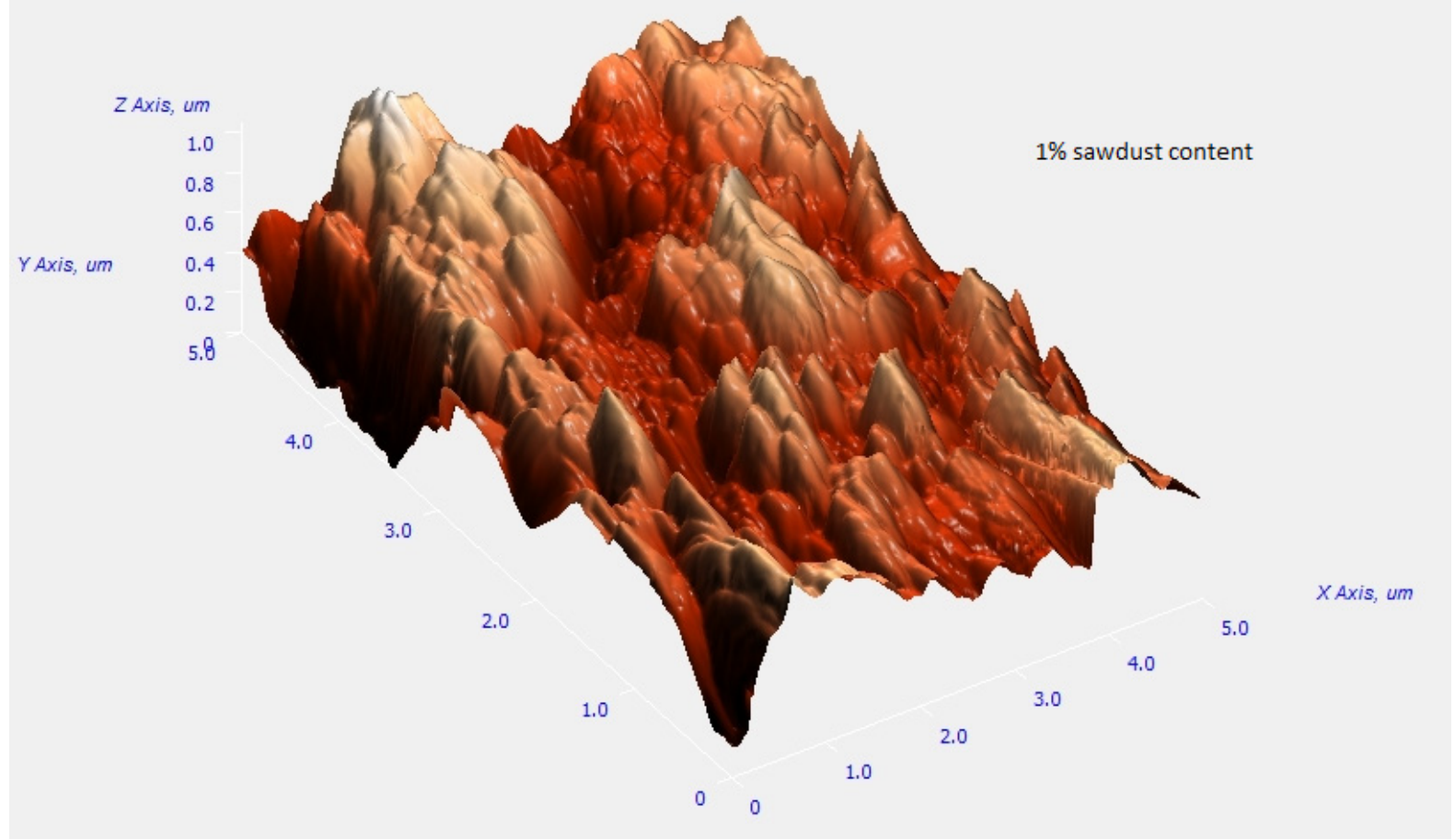

Figure 5. AFM image for $99 \%$ of OPC paste and $1 \%$ sawdust mixture after 28 days

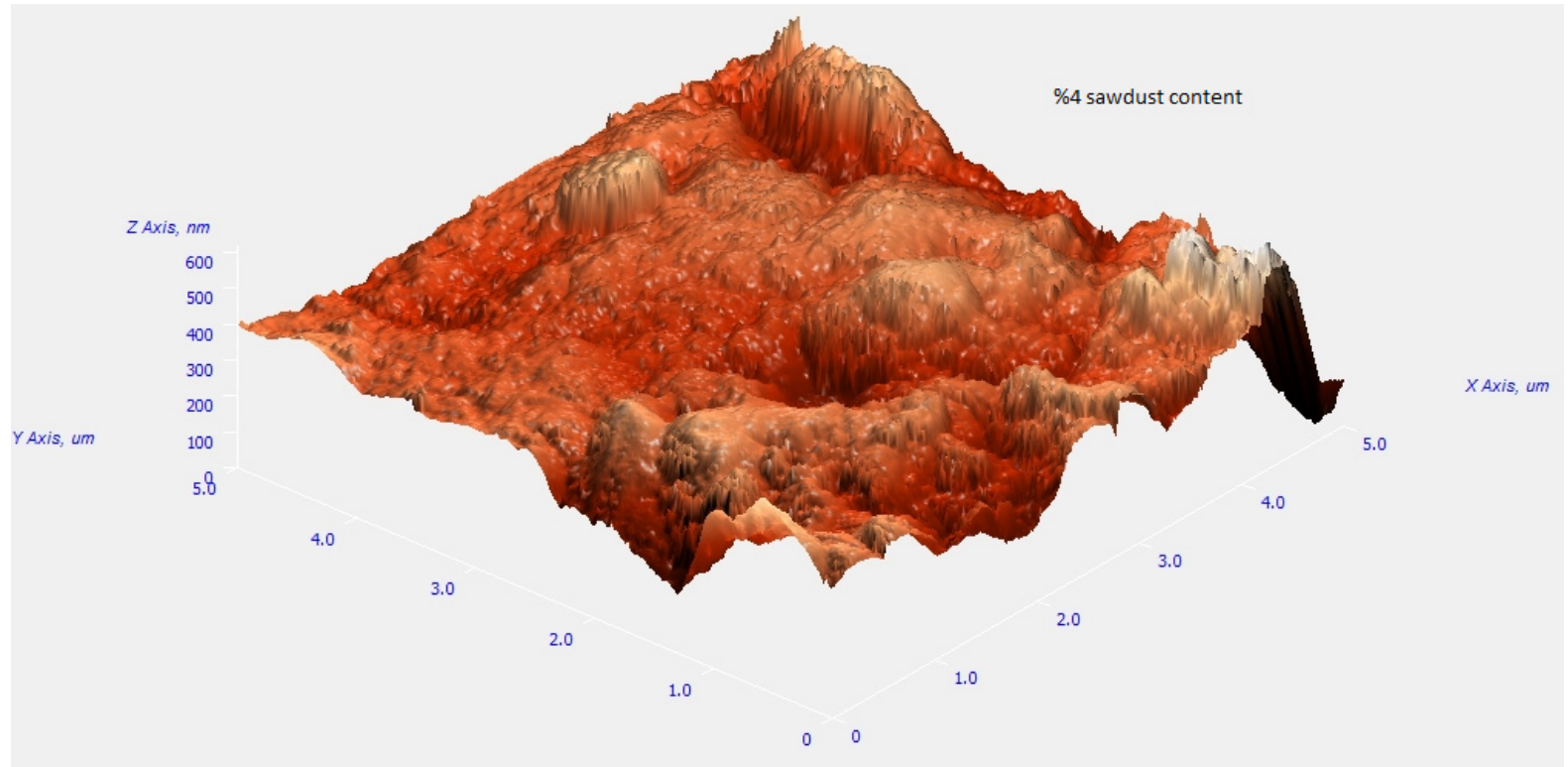

Figure 6 . AFM image for $96 \%$ of OPC paste and $4 \%$ sawdust mixture after 28 days

Cellulose is the main component of sawdust cell walls, and it has complex structure. In this paper, the cellulose-Ibeta is the main mineral of sawdust according to XRD results. The characteristics of cellulose I $\beta$ crystal and surface has been investigated by using AFM and XRD (Figures 3-7). The I $\beta$ crystal increases surface roughness and strength of bonds of cement pastes. The functionalized tissue based on cellulose has been modified surface roughness. The stable I $\beta$ crystallite has been changed cement paste crystalline structures, and subsequently results in change surface roughness. The unit cells have been modified in minor peaks. Experimental findings identify amorphous parts of cellulose with less density. Thin films of cellulose are mainly amorphous. The arrangement of small crystallites connected by less dense, irregular regions accelerates hydration. The hydrogen bonds between the layers have been increased and surface roughness modified. The distance between area peak-to-valley heights in surface has been reduced. The cement paste has significantly 
been changed with respect increase proportion of $\mathrm{I} \beta$. However this modification causes change strength of hydrogen bonds.
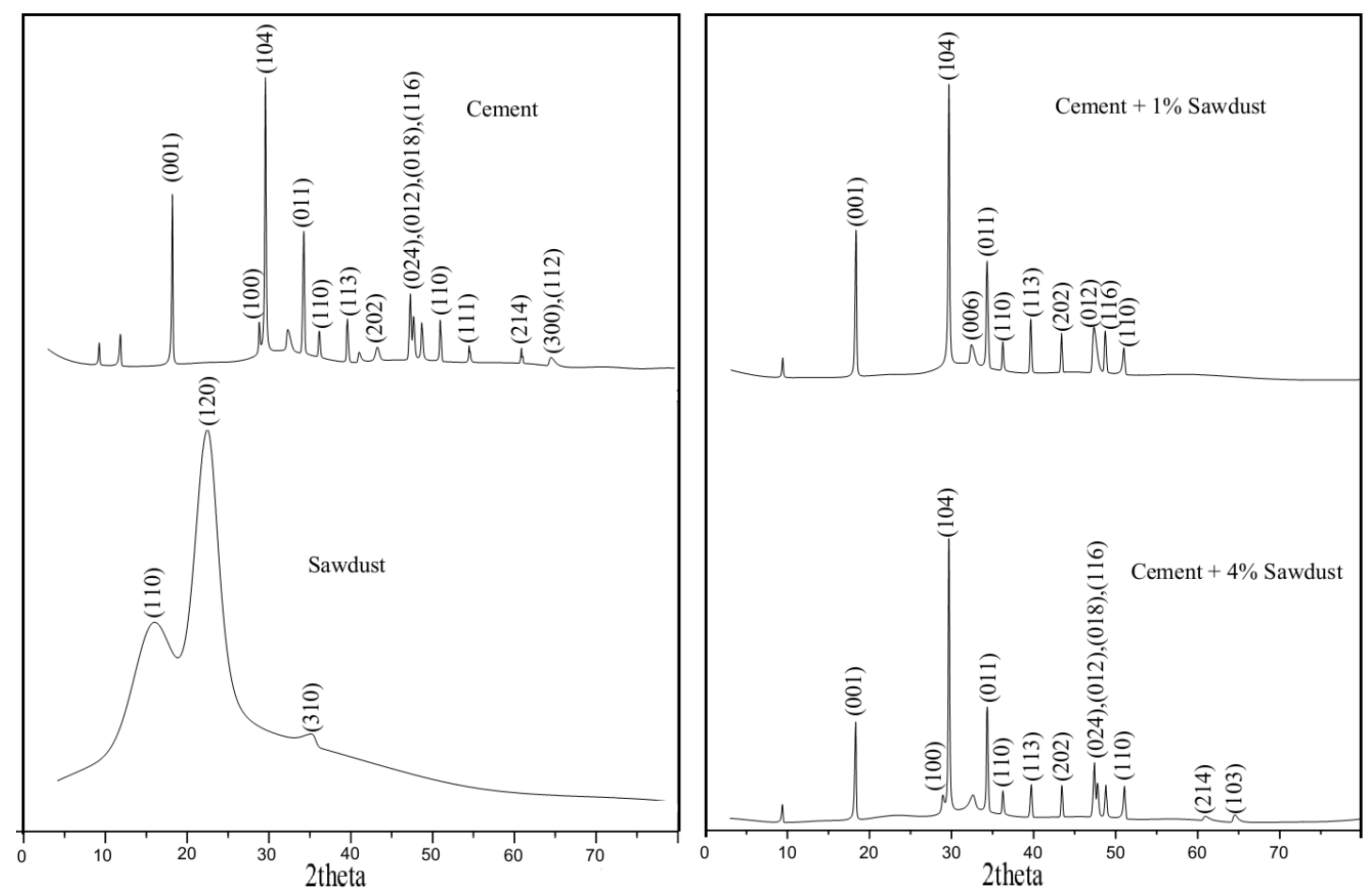

Figure 7. XRD pattern of cement paste, sawdust and cement paste - sawdust mixture

\section{Conclusion}

The result of this paper has good agreement with previous research work is reported (Elinwa \& Mahmood, 2001). The sawdust has been used to improve compressive strength of cement paste. The sawdust enhanced compressive strength of OPC paste in acceptable level. This additive helps environment pollution solution, sustainable development and commercialization of a waste agriculture material. $1 \%$ of sawdust mixture shows best result in short time and 90 days. The Cellulose-Ibeta present in sawdust, modifies surface roughness of OPC paste, and leads to better micro structural bounding of OPC paste. The compressive strength of OPC paste stabilizes in increasing age. The compressive strength of OPC decreases with increase sawdust contents, and stabilized with age due to pozzolanic actions.

\section{References}

Afuwape, A. K. (1983). Design and testing of sawdust compactors. BSc thesis. Ile Ife (Nigeria): Department of Agriculture and Engineering, Obafemi Awolowo University.

Aigbomian, E. P., \& Fan, M. (2013). Development of Wood-Crete building materials from sawdust and waste $\begin{array}{llll}\text { paper. Construction and } & \text { Building }\end{array}$ http://dx.doi.org/10.1016/j.conbuildmat.2012.11.018

Coatanlem, P., Jauberthie, R., \& Rendell, F. (2006). Lightweight wood chipping durability. Constr Build Mater, 20, 776-81. http://dx.doi.org/10.1016/j.conbuildmat.2005.01.057

EFNARC. (2002). Specification and Guidelines for Self-Compacting Con-crete (pp. 1-32). London: EFNARC Publication.

Elinwa, A. U., Ejeh, S. P., \& Mamuda, A. M. (2008). Assessing of the fresh concrete properties of self-compacting concrete containing sawdust ash. Construction and Building Materials, 22, 1178-1182. http://dx.doi.org/10.1016/j.conbuildmat.2007.02.004

Elinwa, A. U., \& Mahmood, Y. A. (2001). Ash from timber waste as cement replacement material. Cem Concr Comp, 24, 219-22. http://dx.doi.org/10.1016/S0958-9465(01)00039-7 
Naik, T. R. (1999). Tests of wood ash as a potential source for construction materials (p. 61). Report no. CBU-1999-09. UWM Center for By-Products Utilization. Department of Civil Engineering and Mechanics, University of Wisconsin-Milwaukee, Milwaukee.

Naik, T. R., Kraus, R. N., \& Siddique, R. (2002). Demonstration of manufacturing technology for concrete and CLSM utilizing wood ash from Wisconsin (p. 124). Report no. CBU-2002-30. Report for year 1 activities submitted to the Wisconsin Department of Natural Resources, Madison, WI, for Project \# 01-06 UWM Center for By-Products Utilization, Department of Civil Engineering and Mechanics, University of Wisconsin-Milwaukee, Milwaukee.

Sales, A., Souza, F. R. D., \& Almeida, F. D. C. R. (2011). Mechanical properties of concrete produced with a composite of water treatment sludge and sawdust. Construction and Building Materials, 25, $2793-2798$. http://dx.doi.org/10.1016/j.conbuildmat.2010.12.057

Siddique, R. (2012). Utilization of wood ash in concrete manufacturing. Resources, Conservation and Recycling, 67, 27-33. http://dx.doi.org/10.1016/j.resconrec.2012.07.004

Turgut, P., \& Algin, H. M. (2007). Limestone dust and wood sawdust as brick material. Building and Environment, 42, 3399-3403. http://dx.doi.org/10.1016/j.buildenv.2006.08.012

Wihersaari, M. (2005). Evaluation of greenhouse gas emission risks from storage of wood residue. Biomass Bioenergy, 28, 444-53. http://dx.doi.org/10.1016/j.biombioe.2004.11.011

\section{Copyrights}

Copyright for this article is retained by the author(s), with first publication rights granted to the journal.

This is an open-access article distributed under the terms and conditions of the Creative Commons Attribution license (http://creativecommons.org/licenses/by/3.0/). 